\title{
Women Economic Empowerment Through Non Timber Forest Products in Gimbo District, South West Ethiopia
}

\author{
Getahun Kassa*, Eskinder Yigezu \\ Department of Agricultural Economics, Mizan-Tepi University, Mizan Teferi, Ethiopia
}

Email address:

zgetah@gmail.com (G. Kassa), eskobar_y@yahoo.com (E. Yigezu)

To cite this article:

Getahun Kassa, Eskinder Yigezu. Women Economic Empowerment Through Non Timber Forest Products in Gimbo District, South West Ethiopia. American Journal of Agriculture and Forestry. Vol. 3, No. 3, 2015, pp. 99-104. doi: 10.11648/j.ajaf.20150303.16

\begin{abstract}
In many communities there are limited income-generating opportunities for women. Fortunately, NTFP activities are one of the few cash-generating opportunities for women in marginalized rural communities. Nevertheless, increasing pressure on forests and biodiversity has increased the pressure on rural women. We investigated the factors influencing the income that women drive from NTFPs collection. In addition, our research also investigated the contribution of NTFPs income for the total annual income of the women and for reducing income inequality in Gimbo District. Two kebeles were selected based on NTFPs availability, level of forest exploitation activities of the people and nearness to road. Data were collected from 120 selected women through structured interviews, focus group discussions, market assessments as well as field observation. Though NTFPs accounted for $53.76 \%$ of the annual income for women, its contribution is affected by different factors. A multiple linear regression model was used to identify factors that affect the income from NTFPs. Out of eight variables included in the regression, four variables such as non NTFPs (other) income, time spent in NTFPs collection, proximity to the forest and distance to market significantly affected the income women derive from NTFP activities. The contribution of NTFPs income in reducing income inequality was analyzed by using Gini Coefficient. Comparing the Gini index with and without NTFPs production (income), the income disparity lowered from 0.40 to 0.27 in the inclusion of NTFPs. Therefore, empowering women through NTFP activities can create significant opportunity for women in terms of income and in reducing income inequality. Thus, policy programs should due attention in improving alternative sources of income for women in the study area.
\end{abstract}

Keywords: NTFPs, Determinants of Women Income, Gini Coefficient

\section{Introduction}

Women often face many disadvantages that hamper their ability to engage in economic activity [1]. A rural woman spends most of her time taking care of her husband, children, elders and other members of her family. Consequently, they become economically dependent and vulnerable, educationally backward as well as politically and socially disadvantaged. These in turn trigger off huge social, economic, and environmental costs on society as a whole and rural development in particular [2]. As women are generally the poorest of the poor, eliminating social, cultural, political and economic discrimination against them is a prerequisite of eradicating poverty [3]. Therefore, attention has been given to poor women's economic empowerment universally to catalyze development efforts.

Economic empowerment increases women's access to economic resources and opportunities including jobs, financial services, property and other productive assets, skills development and market information [4]. Women's economic empowerment is fundamental to enhancing and strengthening their economic and social status. According to Hill [2] rural women's economic empowerment can have a positive impact on their social and political empowerment through their increased respect, status, and self-confidence and increased decision-making power in households, communities, and institutions. It can also shift power relations between women and men by increasing women's control over household budgets [5]. Thus, if given responsibilities to managing critical household assets and natural resources, women are potential agents of change [6].

Around the world, resilient and resourceful rural women contribute in a multitude of ways through different livelihood strategies to lift their families and communities out of poverty 
[2]. Women's enterprise activities have key importance in providing food and income that enable their families to exist [7]. If included in national accounts, this income represents between 15 to 50 percent of national Gross Domestic Products [8]. Considering women's employment, statistics shows that many women are employed in the informal sector and in the non-skilled areas [9]. Fortunately, NTFPs offer greater opportunities for women producers in the informal economy [10].

NTFPs include the product benefits or services that come from a forest except timber [11]. These include plants and plant materials used for food, fuel, storage and fodder, medicine, cottage and wrapping materials, biochemical, as well as animals, birds, reptiles and fishes, for food and feather [12]. It can also be referred as all the resources/products that are extracted from forest ecosystem and utilized within the household or marketed or meant for social, cultural or religious significance [13].

NTFP activities are one of the few cash-generating opportunities for women in marginalized rural communities [14]. Women find NTFP activities attractive because of the low technical and financial entry requirements, freely available resource base and instant cash in times of need [7]. By collecting NTFPs from the forest, women contribute significantly in meeting subsistence requirements and increasing family income [15]. To put it differently, income generated from NTFP activities by women can add significantly to their households' purchasing power [16]. Therefore, empowering women in the forest sector can create significant development opportunities for them and generate important spill over benefits for their households and communities [17].

NTFPs are playing a key role in generating income and improving the livelihood of rural women in Ethiopia. The money earned from collecting, selling or processing forest products has an indispensable contribution to household income [18]. However, the actual contribution of NTFPs to specific rural households especially for women is worth mentioning. Therefore, our research aimed at using a gender vantage point in revealing the role of women in collecting NTFPs; the constraints discouraging their role in NTFP activities; and estimating the contribution of NTFPs for total annual income and for mitigating income inequality in Gimbo District.

\section{Research Methodology}

\subsection{Description of the Study Area}

The study was conducted in Gimbo district, Kaffa zone, Southern Nations Nationalities and People's Region (SNNPR). It is found within the southwestern plateau of Ethiopia and $450 \mathrm{~km}$ and $725 \mathrm{~km}$ far from Addis Ababa and Hawassa respectively. The area lies within $07^{\circ} 00^{\prime}-7^{\circ} 25^{\prime}$ North latitude and $35^{\circ} 55^{\prime}-36^{\circ} 37^{\prime}$ East longitude. The altitude of the study sites ranges from 1600 to 1900 m.a.s.l. The topography is characterized by slopping and rugged areas with very little plain land [19].

\subsection{Data Collection}

Gimbo district was selected purposively based on forest accessibility and availability of NTFPs. Two kebeles were purposively selected from the study area as a result of NTFPs availability, level of forest exploitation activities of the people and nearness to road. A total of 120 women respondents were selected randomly using proportional to size techniques based on the number of female respondents in Kebeles using NTFPs, so that, all sample units had equal chances of being selected. We used a method developed as in [20] to select the total sample size from the total households. Based on rules-of-thumb, "Ref [20]" suggested that the minimum number of respondents for each explanatory variable in a regression analysis should be 5 respondents to 1 explanatory variable. Therefore, in this study there are 10 explanatory variables and the minimum sample size should be 50 . This is the minimum recommended sample size, but it is possible to select the total sample size above the recommended minimum sample size.

For the purpose of this study both primary data and secondary data were collected. Primary data were collected through focus group discussion and interview using semi structured questionnaire. For focus group discussions, women who have good experience in NTFP activities were selected to discuss specific issues related to the purpose of the study by forming small groups (members of 7-8) with homogenous composition. Secondary data were also collected from relevant zonal and district offices in the study area.

\subsection{Data Analysis}

To meet the objectives of the study descriptive statistics, Gini Coefficient and econometric model were used based on their importance for analyzing the quantitative data that have been collected from primary sources. Quantitative data were processed using Statistical Package for Social Sciences SPSS 21 and Microsoft Excel 2007.

Income inequality was measured with the use of the Gini Coefficient. The Gini coefficient is defined as a ratio with values between 0 and 1 . Here, 0 corresponds to perfect income equality (i.e. everyone has the same income) and 1 corresponds to perfect income inequality (i.e. one person has all the income, while everyone else has zero income).

To answer the question of factors influencing the rural women income from NTFP production, econometric model was used. Factors influencing rural women income from NTFPs were estimated using multiple linear regressions model ([21]; [22]). The total monetary value of the various types of NTFPs collected by each woman per year is found to be the most appropriate unit of measurement to identify the factors that influence the rural women income from NTFPs. In this case, income (monetary value) derived from NTFPs by each woman was considered as dependent variable. The following econometric model was employed: 


$$
\mathrm{Y}=\beta_{\mathrm{o}}+\beta_{\mathrm{i}} \mathrm{X}_{\mathrm{i}}+\varepsilon
$$

Where: $\mathrm{Y}=$ income derived from NTFPs;

$\beta \mathrm{o}=$ intercept (the value of $\mathrm{Y}$ when $\mathrm{X}=0$ )

$\beta \mathrm{i}=\mathrm{a}$ vector of estimated coefficient of the explanatory variables and;

$\mathrm{Xi}=$ explanatory variables

$\varepsilon=$ the stochastic disturbance term

\section{Result and Discussion}

\subsection{Household Characteristics}

Of the total respondents, $95 \%$ were married, $2.5 \%$ of them were single and the remaining $2.5 \%$ of them were divorced. Having 95\% married respondents has a good advantage in providing financial support for husband and children. Regarding their religion, $77.5 \%$ of them were the followers of the Ethiopian Orthodox Thewahido, $16.67 \%$ were Protestant and the remaining $5.83 \%$ of them were followers of other religions in the country. With regard to ethnic composition of the respondents, Kaffa was the dominant group accounted for $79.17 \%$ of the total respondents, about $16.67 \%$ belonged to the Menja ethnic group and $4.16 \%$ were the remaining ethnic groups of the country. The uniqueness in the study area is that the Menja ethnic minorities consists the second largest percentage of the forest users in the study area. The Menja minorities are highly dependent on the forest as a means of livelihood.

Table 1. Socioeconomic Characteristics of the Respondents.

\begin{tabular}{lllll}
\hline Variables & Minimum & Maximum & Mean & St. Deviation \\
\hline Age & 20 & 60 & 33.53 & 9.34 \\
Family size & 2 & 9 & 5.24 & 1.90 \\
Education & 0 & 10 & 1.69 & 2.70 \\
\hline
\end{tabular}

Source: Household Survey (2015)

The mean age of the respondents was 33.53 years. The largest proportion of the respondents $(94.17 \%)$ lay in the age range of 20-50 years. This implies the majority of the respondents were active work forces. The mean family size of the respondents was 5.25. With regard to educational attainment of the respondents, the mean educational attainment was 1.69 grades. The majority of the respondents $(63.33 \%)$ were unable to read and write.

\subsection{Major NTFPs Collected by Women}

The women in the study area exploited various NTFPs like forest coffee, honey, feral honey, spices (Cardamom and long pepper), fuel wood, charcoal, bamboo and medicinal plants from the forest. The NTFPs were classified based on their importance for commercial as well as house use only. According to the information gathered through focus group discussion, women classified NTFPs like forest coffee, forest honey and spices as important NTFPs that generate them significant contribution of cash income. On the other hand, the women extracted fuel wood, charcoal, bamboo and medicinal plants for house-use only.

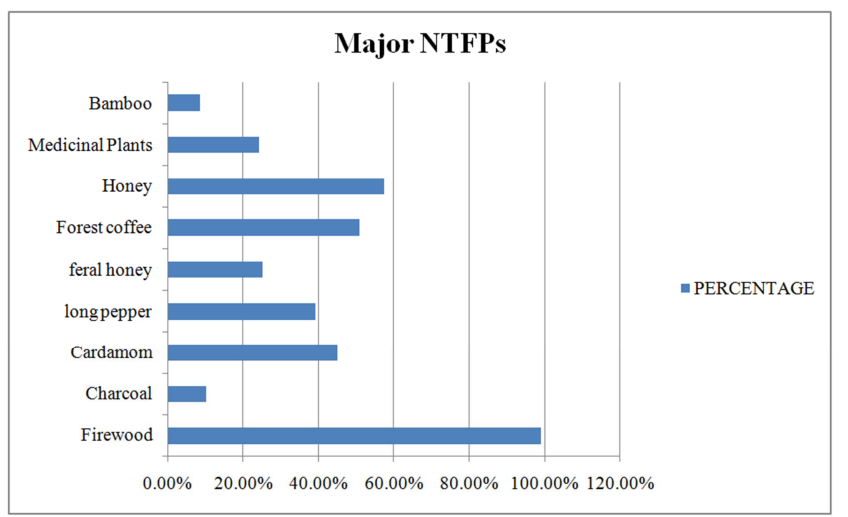

Source: Household Survey (2014)

Figure 1. Major NTFPS.

The figure (Figure 1) shows the majority of the women harvested fuel wood from near communal or state forests every day to meet the daily energy demand in the household. Charcoal is another source of energy that the women extracted from the forest. Our finding is consistent with the findings of those of [23] who reported wood fuel as the most common source of NTFPs income for $68 \%$ of households. Another finding as in "Ref. [24]" revealed that firewood constitutes the largest proportion (59\%) of forest income.

In our finding, it is found that forest coffee, honey and spices were the most important cash generating NTFPs. In line with this, "Ref. [25]" revealed that $33 \%$ of households generate cash income by selling forest coffee. "Ref. [18]" also revealed that the benefits received from beekeeping encourage the preservation of the forest in South West Ethiopia.

\subsection{Contribution of NTFPs for Women Income}

Women in the study area earned income from limited sources such as agriculture (mainly crop production) and forests (NTFPs). There are limited economic opportunities in the study area which hindered the women from diversifying their sources of income. As a result, the women living at the proximity of the natural forest depend highly on the forest to extract many NTFPs.

Table 2. Sources and Proportion of Women Income.

\begin{tabular}{llll}
\hline No & Sources & Income & Percentage \\
\hline 1. & Agriculture (non NTFPs) & $1,340.50$ ETB & $46.24 \%$ \\
2. & NTFPs & $1,558.78$ ETB & $53.76 \%$ \\
& Total & $2,899.28$ ETB & $100 \%$ \\
\hline
\end{tabular}

Source: household survey (2014)

NTFPs production was the main source of income (53.76\%) for the women in the study area. Consistent with our findings, a study conducted in Nigeria revealed that the major source of income to the household is the income from NTFPs [26]. As in "Ref. [27]" in Southern Ethiopia forest products constitute an important part of the household income portfolio contributing $34 \%$ of total per capita income. "Ref. [23]" also supported that NTFPs account for about one third of total household income. 


\subsection{Role of NTFPs Income in Reducing Income Inequality}

The figures (Figure $2 \& 3$ ) show the impact of NTFPs income on income inequality. Lorenz curves with the data for households' income including or excluding show that addition of NTFPs income to total income reduces the departure of the curve from the line of equal distribution.

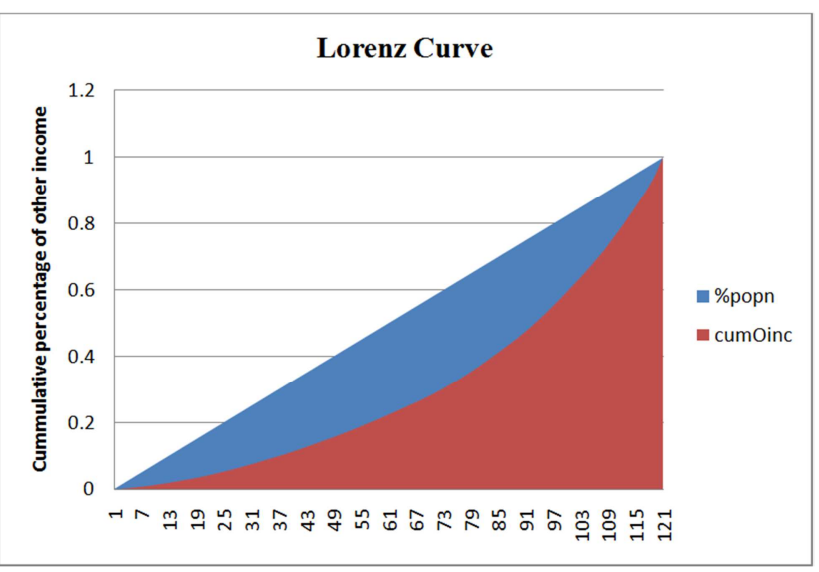

Figure 2. Lorenz Curve without NTFPs Income.

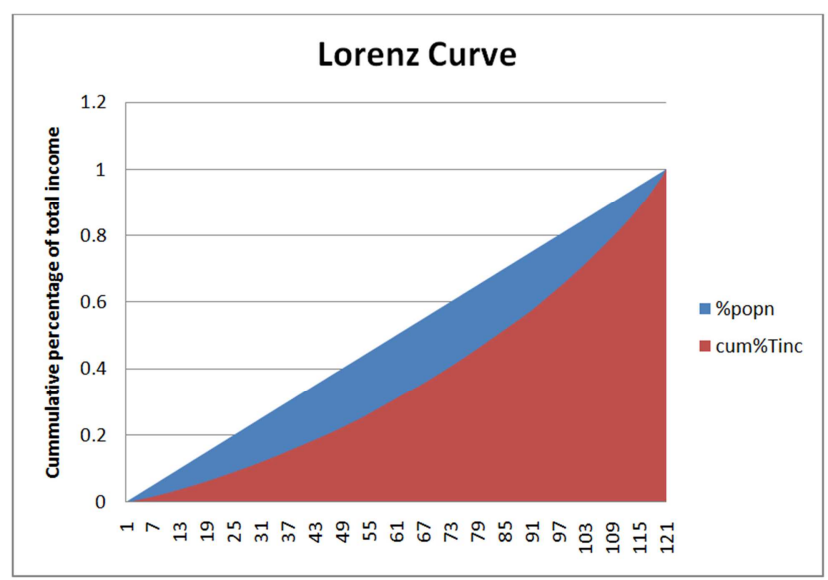

Figure 3. Lorenz Curve with the inclusion of NTFPs Income.

The Gini index for other incomes (non NTFPs income) is 0.40 . This index is higher than the national value of Gini index (0.34) set by World Bank for the year 2014 [28]. However, when income from NTFPs was included in the total annual income for the women, the Gini index was calculated at 0.27. Comparing the Gini index with and without NTFPs production (income), the disparity was lowered by a coefficient of 0.13 in the inclusion of NTFPs. The result shows NTFPs play greater role in reducing income inequality among women in the study area.

Table 3. Gini Coefficient for the two income sources.

\begin{tabular}{llll}
\hline No & CASES & $\begin{array}{l}\text { GINI INDEX } \\
\text { (PERCENTAGE) }\end{array}$ & $\begin{array}{l}\text { GINI } \\
\text { COEFFICIENT }\end{array}$ \\
\hline 1. & Other income & $39.55 \%$ & 0.40 \\
2. & Total income & $27.05 \%$ & 0.27 \\
& Change in Gini index & $12.5 \%$ & 0.13 \\
\hline
\end{tabular}

Ethiopian National Gini in 2014 is $33.6 \%$ (BTI, 2014)
In line with our finding, in Southern Ethiopia NTFPs income from gum and resin contributed to the reduction of the measured income inequality from 0.47 to 0.22 [29]. Another finding in Burkina Faso revealed that if forest (TFPs and NTFPs) sources of income are excluded from analysis, the estimated Gini coefficient increases from 0.47 to 0.89 which shows that addition of forest income reduces measured income inequality of $42 \%$ [30]. In "Ref. [27]" it is indicated that the increase in Gini coefficient becomes highest when forest income is excluded (0.45). Our study also concurs with the finding in "Ref. [24]" which indicated that income inequality is 0.28 when forest incomes are included, but the coefficient rises to 0.41 when forest incomes are excluded.

\subsection{Determinants of Income from NTFPs}

The multiple linear regression analysis was carried out to identify the factors influencing rural women income from NTFPs. The $\mathrm{F}$ test shows that the model is significant at less or equal to $0.000 \%$ probability level. The $\mathrm{R}^{2}$ value of 0.607 indicates the explanatory power of the model. Thus, $60.7 \%$ of the variation in the dependent variable was explained by the regression. Explanatory variables such as educational attainment of the respondents (educ), the experience of rural women in collecting the NTFPs (experie), family size (Fsize) and time spent in the forest (Tspent) exhibited positive relation to income derived from NTFPs. But, age of the respondents (AGE), other income of the respondents (Oincome), proximity to the forest (DISFOREST) and distance to the market (DISMARKET) showed negative relation to income derived from NTFPs. However, out of the total variables, four were statistically significant at 10,5 and $1 \%$ probability level. These were other (non NTFPs) income, time spent in the forest, proximity to the forest and distance to the market from the residence of respondents.

Table 4. Factors Influencing Women Income from NTFPs.

\begin{tabular}{lllll}
\hline Variables & Coefficients & $\begin{array}{l}\text { Std. } \\
\text { Error }\end{array}$ & $\begin{array}{l}\text { t } \\
\text { statistics }\end{array}$ & significance \\
\hline Constant & 2370.79 & 577.74 & 4.10 & .00 \\
Age & -11.67 & 16.09 & -.73 & .47 \\
Education & 38.15 & 36.05 & 1.06 & .29 \\
Oincome & -.14 & .06 & -2.26 & $.03 * *$ \\
Famsize & 13.09 & 52.13 & .25 & .80 \\
Experience & 9.98 & 31.59 & .32 & .75 \\
Tspent & 405.37 & 62.32 & 6.50 & $.00^{* * *}$ \\
Pforest & -2347.98 & 372.92 & -6.30 & $.00^{* * *}$ \\
Dmarket & -215.98 & 116.55 & -1.85 & $.07 *$ \\
\hline
\end{tabular}

$* * *, * *$, and $*$ refer to significance at less than $1 \%, 5 \%$, and $10 \%$ probability levels, Dependent Variable: income from NTFPs, N=120, R-Square $=0.634$, Adjusted R2=0.607, F=24.012

As predicted, proximity to the forest negatively affected the income from NTFPs at less than 1\% significance level. Therefore, those residing far away from the forest are less interested in NTFP activities because of higher transaction cost. In line with our finding, a study conducted in Bonga Forest revealed that the negative and significant effect of distance to forest on income from NTFPs was due to the 
increase in cost of production [25]. Another study conducted in Nigeria noted that the negative association between income from NTFPs and distance to the forest may results from large transportation cost, if large quantities of NTFPs are gathered [26]. Another finding also noted that the negative association between distances of house from forest with share of forest income gives an idea that people nearby forest had more access to forest, easy to reach there and were more benefited [31]. A research conducted in Nigeria concluded that as one gets farther away from the forest area, she/he tends to use less of the forestry resource [32].

In our study, time spent in the forest positively affected the income from NTFPs at less than $1 \%$ significant level. This means those individuals who spent more time in the forest collect more quantity of NTFPs. Women devote their time in NTFPs collection if the return they earn from it is attractive. Therefore, the more time spent in the forest, the higher is the income women drive from NTFPs.

Other income (non NTFPs income) was another variable found to be negatively associated with NTFPs income. The negative association between other income and NTFPs income indicates if women receive more income from other activities, they will be less reliant on NTFPs income. Therefore, the higher income women drive from other sources; they will be less attracted to NTFPs. In line with our finding, "Ref. [33]" revealed that negative association between cash income per capita and the share of income generated by NTFPs. This happens because of low income from other sources, people have to collect commercial NTFPs to increase their household income [34].

Another important variable that significantly affected women income from NTFPs is distance to market. We found a negative association between distance to market from the residence of respondents and NTFPs income at less than $10 \%$ significance level. This means longer distance discourages women from being engaged in NTFP activities due to high transaction costs. Consistent with our finding, "Ref. [25]" and "Ref. [26]" revealed that distance from forest to point of sale has a negative and significant effect on NTFPs income which may results from large transportation cost. In "Ref. [23]" it is concluded that the farther away a household is from the market, the lower the likelihood to participate in NTFPs and also the less dependent a household is on income from NTFPs.

\subsection{Conclusions and Policy Implications}

The main source of income for women in the study area consist agriculture (mainly crop production) and NTFP activities. With such limited income sources, NTFPs played an important role in contributing to women income (53.76\%) and mitigating income inequality. Comparing the Gini index with and without NTFPs production (income), the income disparity lowered from 0.40 to 0.27 in the inclusion of NTFPs. However, the contribution of NTFPs income for women is influenced by several factors. Time spent in NTFPs collection, proximity to the forest, non NTFPs income and distance to market significantly influenced the income women derive from NTFP activities. Therefore, empowering women through NTFP activities can create significant opportunity for women in terms of income generating and in reducing income inequality if attention is due for the factors that affect NTFPs income in the study area.

Based on the findings of our study, the following policy directions are recommended;

- Income derived from NTFPs extraction contributed significantly to the annual income of sampled women in the study area. Therefore, women economic empowerment policies should give emphasize to the importance of NTFPs by considering it as alternative income generating source for rural women due to its international recognition and usefulness of NTFPs.

- Second, in terms of mitigating income inequality, the result suggested that income inequality can be reduced through the inclusion of NTFPs income. Therefore, inequality should be reduced through policy programs that improve alternative sources of income for women in the study area.

- Distance to market affected the income that women derive from NTFPs. This underscores the importance of improving access to market in order to encourage rural women to diversify into NTFP business activities and increase their income.

- Finally, distance to the forest discouraged the women in the study area from being engaged in NTFP activities. Therefore, the women should be encouraged to domesticate minor forest products in their backyards outside the community forest area.

\section{Acknowledgments}

This research is the result of a successful collaborative effort by many individuals and we would like to pay tribute to all individuals who contributed to this work. We are highly indebted to Belachew Adulo, Mulualem and Kasech for their support while collecting the data. We would also like to thank Mizan-Tepi University for providing us the necessary financial support to conduct our work. Our special appreciation goes to Gimbo District Agricultural office for the cooperation to conduct our research in the area. Lastly, we would like to thank Dr. Yared Berhanu.

\section{References}

[1] Carr M, (2008). Gender and non-timber forest products: Promoting food security and economic empowerment. International Fund for Agricultural Development (IFAD), Italy.

[2] Hill C, (2011). Enabling Rural Women's Economic Empowerment: Institutions, Opportunities, and Participation.

[3] International Conference on Population and Development (ICPD), 1994. Program of Action

[4] OECD, (2012). Promoting Pro-Poor Growth: The Role of Empowerment. The OECD DAC Network on Gender Equality (GENDERNET) 
[5] Esplen E, and Brody A, (2007). Putting Gender Back in the Picture: Rethinking Women's Economic Empowerment. Report prepared at the request of the Swedish International Development Cooperation Agency (Sida); Bibliography No. 19

[6] International Fund for Agricultural Development (IFAD), 2014 The Gender Advantage. Women on the Front of Climate Change.

[7] International Fund for Agricultural Development (IFAD), (2008). Gender and non-timber forest products. Promoting food security and economic empowerment.

[8] Budlender, D, ( 2010). 'What Do Time Use Studies Tell us about Unpaid Care Work? Evidence from Seven Countries', in Time Use Studies and Unpaid Care Work, ed. Budlender, UNRISD; Hoenig S. A. and Page, A.R.E, 2012, Counting on Care Work in Australia, Report prepared by AECgroup Limited for economic Security4women, Australia; Charmes, J. and J. Unni (2004), "Measurement of work", in G. Standing and M. Chen eds., Reconceptualising Work, International Labour Organization.

[9] Mersha G, (2007). Gender Mainstreaming In Forestry in Africa; Ethiopia. Food and Agriculture Organization of the United Nations Rome, 2007

[10] International Fund for Agricultural Development (IFAD), 2010 Gender and Desertification. Expanding roles for women to restore dry land areas enabling.

[11] Wong J, (2000). The biometrics of non-timber forest product resource assessment: A review of current methodology.

[12] Adepoju, Adebusola A, Salau, Sheu A, (2007). Economic Valuation of Non-Timber Forest Products (NTFPs), Univerisity of Ibbadan, Ibbadan.

[13] Food and Agricultural organization (FAO), (1990). Major Significance of Minor Forest Product: The Local Use and Value of Forest in the West African Humid Forest Zone. Community Forestry Note 6 Rome.

[14] Schreckenberg K, and Marshall E, (2006). Women and NTFPs: Improving income and status? In: Marshall E, Schreckenberg K, and Newton A.C, (eds.) Commercialization of non timberforest products: Factors influencing success. UNEPWCMC, Cambridge. 136p

[15] World Wildlife Fund UK (WWF-UK), (2012). Forest Management and Gender.

[16] Food and Agricultural Organization (FAO), (2014). Women in Forestry: Challenges and Opportunities

[17] FAO, (2013). Forests, food security and gender: linkages, disparities and priorities for action. Background paper for the International Conference on Forests for Food Security and Nutrition, FAO, Rome, 13-15 May, 2013

[18] Mohammed A, Tadesse W, and Abebe Y, (2006). Counting on Forests: Non-Timber Forest Products and Their Role in the Households and National Economy in Ethiopia. Published in Agricultural Economics Society of Ethiopia (AESE): Commercialization of Ethiopian Agriculture, Proceedings of the 8th Annual Conference of Agricultural Economics Society of Ethiopia, February 24-26, 2005, Addis Ababa.
[19] Matheos E, (2001). Inventory of woody species in Bonga Forest. Institute of Biodiversity Conservation and Research. Technical Report No. 1. Addis Abeba.

[20] Tabachnick, B. G., \& Fidell, L. S. (1989). Using Multivariate Statistics. 2nd edition. Cambridge, MA: Harper \& Row.

[21] Gujarati D, (2004). Basic Econometrics. Fourth edition. New York. The McGraw-Hill Companies.

[22] Wooldridge J, (2005). Introductory Econometrics. A modern Approach. Third Edition. Thomson South Western.

[23] Mulenga B, Richardson R, and Tembo G, (2012). Non-Timber Forest Products and Rural Poverty Alleviation in Zambia, Working Paper No. 62, April 2012

[24] Getachew M, Sjaastad E, and Velded P, (2007). Economic dependence of forest resource: case from Dendi District, Ethiopia. Forest Policy and Economics 9:916-927.

[25] Ermias M, Zeleke E, and Demel T, (2014). Non-timber forest products and household incomes in Bonga forest area, southwestern Ethiopia. Journal of Forestry Research (2014) 25(1): 215-223

[26] Raufu M, Akinniran T, Olawuyi S, and Akinpelu M, (2012). Economic Analysis Of Rural Women Income From Non-Timber Forest Products In Ife South Local Government Area of Osun State, Nigeria. Global Journal of Science Frontier Research Agriculture \& Biology; Volume 12 Issue 1 Version 1.0 January 2012

[27] Yemiru T, Roos A, Campbell B, and Bohlin F, (2010). Forest Incomes and Poverty Alleviation under Participatory Forest Management in the Bale Highlands, Southern Ethiopia. International Forestry Review 12(1):66-77.

[28] Bertelsmann Stiftung's Transformation Index (BTI), (2014). Ethiopia Country Report. Gütersloh: Bertelsmann Stiftung, 2014.

[29] Asmamaw A, Pretzsch J, Secco L, and Mohamod T, (2014). Contribution of Small-Scale Gum and Resin Commercialization to Local Livelihood and Rural Economic Development in the Dry lands of Eastern Africa. Forests 2014, 5, 952-977

[30] Ouedraogo B, and Ferrari S, (2012). Incidence of forest income in reducing poverty and inequalities: Evidence from forest dependent households in managed forests' areas in Burkina Faso. Cahiers du GREThA, n²012-28.

[31] Khanal B, (2013). Determinants of Farmers' Income from Community Forestry in Nawalparasi, Nepal. The Journal of Agriculture and Environment Vol: 14, Jun.2013

[32] Onoja A, and Unaeze H, (2009). Forest Income Determinants among Rural Households of Etche Local Government Area, Rivers State, Nigeria. Journal of Sustainable Development in Africa (Volume 11, No.3, 2009)

[33] Rodríguez F, (2007). Socio- economic Determinants of Non-Timber Forest Products Collection. A case study among indigenous people in Karnataka, India

[34] Quang D, and Anh T, (2006). Commercial collection of NTFPs and Households living in or near the forests; case study in Que, Con Coung and Ma, Toung Doung, Ghe An, Vietnham. Ecological Economics 60 (2006): 65-74 